\title{
Analisis Minat Belajar Siswa dalam Penggunaan Aplikasi Belajar Quizizz pada Pembelajaran Tematik Kelas III Sekolah Dasar
}

\author{
Dewi Nur Yulistiarawati*, Siti Umayaroh, Yulia Linguistika \\ Universitas Negeri Malang, Jl. Semarang No. 5 Malang, Jawa Timur, Indonesia \\ *Penulis korespondensi, Surel: dewi.nur.1701516@students.um.ac.id
}

Paper received: 5-7-2021; revised: 23-7-2021; accepted: 30-7-2021

\begin{abstract}
The purpose of this study was to describe the learning interest of class III B students at SDN Bumiayu 3 Malang City when learning without using the Quizizz learning application and to describe the learning interests of class III B students at SDN Bumiayu 3 Malang City when learning using the Quizizz learning application. The approach used is a mix method (combination research) with the type of research using descriptive research and the design method used is the parallel combined method design. Data were collected using a questionnaire (questionnaire), interviews and documentation. The results of the study showed that students' interest in learning without using the Quizizz learning application was categorized as moderate with a percentage of 63 percent. Then for students' interest in learning using the Quizizz learning application, the percentage of 83 percent is in the high category. There is an increase in interest in learning, namely 20 percent, so it can be concluded that the Quizizz learning application can be an alternative for teachers in using learning media during online learning during a pandemic to increase students' interest in learning, as well as create a more interesting, fun, not monotonous learning atmosphere for learning. followed by students, and utilize technology.
\end{abstract}

Keywords: student interests; quizizz learning applications; elementary school student

\begin{abstract}
Abstrak
Tujuan penelitian ini adalah mendeskripsikan minat belajar peserta didik kelas III B SDN Bumiayu 3 Kota Malang ketika pembelajaran tanpa menggunakan aplikasi belajar Quizizz dan mendeskripsikan minat belajar peserta didik kelas III B SDN Bumiayu 3 Kota Malang ketika pembelajaran menggunakan aplikasi belajar Quizizz. Pendekatan yang digunakan yaitu mix method (penelitian kombinasi) dengan jenis penelitian menggunakan penelitian deskriptif dan desain metode yang digunakan yaitu desain metode gabungan paralel. Data dikumpulkan menggunakan kuesioner (angket), wawancara, dan dokumentasi. Hasil dari penelitian menunjukkan bahwa minat belajar peserta didik tanpa menggunakan aplikasi belajar Quizizz dikategorikan sedang dengan persentase 63 persen. Kemudian untuk minat belajar peserta didik menggunakan aplikasi belajar Quizizz menunjukkan persentase 83 persen yang termasuk kategori tinggi. Terdapat peningkatan minat belajar yaitu 20 persen, sehingga dapat disimpulkan bahwa aplikasi belajar Quizizz dapat menjadi alternatif guru dalam menggunakan media pembelajaran selama pembelajaran dalam jaringan di masa pandemi guna meningkatkan minat belajar peserta didik, serta menciptakan suasana pembelajaran yang lebih menarik, menyenangkan, tidak monoton untuk diikuti peserta didik, dan memanfaatkan teknologi.
\end{abstract}

Kata kunci: minat belajar; aplikasi belajar quizizz; siswa SD

\section{Pendahuluan}

Pandemi covid-19 berdampak pada semua sektor dalam kehidupan termasuk pendidikan di Indonesia. Adanya inovasi kurikulum perlu disesuaikan dengan penerapan kegiatan pembelajaran di lapangan. Pembelajaran pada era pandemi covid-19 ini yang 
terpenting yaitu meningkatkan performansi dari personal peserta didik (Praherdhiono dkk., 2020). Oleh sebab itu, pelaksanaan pembelajaran yang diterapkan harus menyesuaikan dengan kondisi kebutuhan peserta didik pada saat ini. Pembelajaran era pandemi covid-19 ini dilaksanakan secara dalam jaringan (daring) atau online. Kegiatan belajar dan mengajar dilaksanakan secara dalam jaringan atau daring ini, guna memutus rantai penyebaran virus covid-19. Proses kegiatan belajar mengajar yang biasanya dilaksanakan tatap muka di dalam kelas, kini harus diubah untuk menjaga keselamatan pendidik maupun peserta didik (Gusty, dkk., 2020). Pemanfaatan teknologi sangat dibutuhkan pada pembelajaran yang dilakukan secara dalam jaringan atau daring ini. Teknologi hadir sebagai media pembelajaran yang memberikan kemudahan untuk peserta didik dan guru dalam proses pembelajaran (Nissa \& Haryanto, 2020). Perkembangan teknologi yang terus berkembang menghasilkan media pembelajaran yang efektif dan efisien berbasis TIK (Aini, 2019). Pencarian bahan ajar sebagai materi pembelajaran atau pemanfaatan berbagai video pembelajaran yang telah tersedia gratis dan dapat diakses di berbagai situs-situs pendidikan sebagai penunjang pembelajaran sangat dibutuhkan pada saat seperti ini (Pujiasih, 2020). Guru sebagai tenaga pendidik juga harus selalu memiliki inovasi dan invensi guna meningkatkan minat belajar peserta didik.

Minat belajar peserta didik dapat meningkatkan ketekunan belajar yang berdampak pada keberhasilan peserta didik dalam mencapai tujuan pembelajaran. Apabila peserta didik memiliki minat belajar yang tinggi, maka peserta didik akan memberikan perhatian yang lebih dan merasakan senang ketika belajar serta memiliki waktu khusus untuk belajar (Simbolon, 2014). Indikator minat belajar yakni perasaan senang, perasaan tertarik, penuh perhatian, bersikap positif, dan terpenuhinya kebutuhan (Kartini, 2007). Pendapat lain indikator minat belajar yaitu perasaan senang, ketertarikan, penerimaan dan keterlibatan (Slameto, 2010). Kemudian indikator yang digunakan pada penelitian ini yaitu perasaan senang, ketertarikan, perhatian, dan keterlibatan.

Salah satu cara yang dapat dilakukan guru untuk meningkatkan minat belajar peserta didik yaitu menjadikan kegiatan belajar dan mengajar lebih menarik dengan memanfaatkan berbagai macam model dan teknik pembelajaran, serta menggunakan media pembelajaran yang inovatif dan komunikatif (Djamarah, 2011). Aplikasi yang dapat dijadikan media pembelajaran terutama yang memanfaatkan teknologi dalam implementasinya kini sudah tersedia dengan banyak (Muis, 2019). Lembaga-lembaga pendidikan berusaha menyediakan fasilitas Learning Management System (LMS) untuk membantu guru dalam memanfaatkan teknologi dalam implementasi kegiatan pembelajaran (Gusty, dkk., 2020). Guru tidak perlu bingung lagi karena aplikasi belajar berbasis permainan kini sudah banyak dan bisa dilakukan secara online. Manfaat yang diperoleh dalam penggunaan aplikasi belajar berbasis permainan yaitu menjadikan peserta didik lebih aktif, suasana pembelajaran yang lebih dinamis dan menambah pengalaman belajar secara umum (Amri \& Shobri, 2020). Aplikasi belajar berbasis permainan salah satunya yaitu aplikasi belajar Quizizz.

Quizizz merupakan satu diantara banyak aplikasi belajar berbasis permainan yang dimanfaatkan sebagai penunjang kegiatan belajar dan mengajar. Quizizz merupakan aplikasi belajar berbasis permainan yang mewadahi aktivitas multi pemain sehingga menjadikan kegiatan belajar dan mengajar lebih interaktif dan menyenangkan (Purba, 2019). Aplikasi Quizizz didirikan pada tahun 2015 oleh Deepak Joy Cheenath dan Ankit Gupta dari Bengaluru, India. Aplikasi Quizizz membantu guru dalam menyajikan kuis yang menarik untuk para peserta didiknya. Tidak hanya kuis, aplikasi Quizizz juga menyajikan fitur baru yang menarik 
yaitu Lessons (Quizizz, 2020). Guru dapat menggunakan fitur Lessons sebelum, setelah, dan selama kelas. Fitur Quiz dan Lessons ini dapat digunakan secara gratis. Guru bebas membuat Quiz dan Lessons sendiri atau menggunakan Quiz dan Lessons yang sudah ada pada perpustakaan Quizizz. Pembelajaran menggunakan aplikasi belajar Quizizz memiliki kelebihan mampu menumbuhkan kemampuan berpikir kritis (Citra \& Rosy, 2020). Kelebihan aplikasi belajar Quizizz yang lain diantaranya: 1) Soal yang telah dibuat dapat digunakan di lain waktu. 2) Dapat saling membagikan soal kuis dengan akun aplikasi Quizizz yang lainnya. 3) Dapat dikerjakan dimana dan kapan saja. 4) Hasil kuis dapat dilihat dalam berbagai macam output (Dayanti, dkk., 2020). Adapun kelemahan aplikasi belajar Quizizz yaitu; 1) Harus membutuhkan jaringan internet yang stabil. 2) Membutuhkan perangkat seperti komputer atau gadget. 3) Soal yang sudah dijawab tidak bisa diulang kembali. 4) Tidak bisa memilih mengerjakan soal yang mudah terlebih dahulu (Dayanti, dkk., 2020).

Pada pembelajaran dalam jaringan di kelas III SDN Bumiayu 3 Kota Malang berdasarkan hasil observasi kegiatan pembelajaran menggunakan aplikasi WhatsApp Group sebagai media komunikasi antara guru dengan peserta didik. Aplikasi WhatsApp Group dinilai sebagai aplikasi yang mudah untuk dijangkau oleh para wali murid atau orang tua peserta didik. Hal ini dikarenakan telepon genggam atau gadget yang digunakan sebagai media pembelajaran dalam jaringan merupakan milik orang tua peserta didik. Berdasarkan hasil observasi kegiatan pembelajaran secara langsung peserta didik menyukai kegiatan pembelajaran yang menarik. Beberapa di antara peserta didik merasa bosan dan mengeluh dengan pembelajaran yang monoton. Hal ini terlihat dari antusias peserta didik dalam mengumpulkan tugas yang diberikan oleh guru. Terdapat beberapa peserta didik yang tidak mengumpulkan atau mengumpulkan tugas dalam kurun waktu yang lama. Peserta didik menyukai pembelajaran yang dikaitkan dengan permainan atau yang biasa disebut bermain sambil belajar. Hal tersebut dapat terlihat ketika peneliti memberikan video pembelajaran yang menarik dan kuis melalui Google Form. Minat belajar peserta didik meningkat terbukti dari hasil belajar peserta didik pada materi pembelajaran yang disampaikan. Peneliti ingin mendeskripsikan minat belajar peserta didik di kelas III di SDN Bumiayu 3 Kota Malang dalam penggunaan aplikasi belajar Quizizz.

Berdasarkan hasil observasi, hasil studi dokumen, dan kajian penelitian yang relevan mengenai minat belajar peserta didik dalam penggunaan aplikasi belajar Quizizz ini layak untuk dilakukan. Peneliti mengambil fokus masalah tentang minat belajar peserta didik kelas III dalam penggunaan aplikasi belajar Quizizz pada pembelajaran tematik dilihat dari indikator minat belajar yaitu perasaan senang, ketertarikan, perhatian, dan keterlibatan. Penelitian ini bertujuan untuk menganalisis dan mendeskripsikan minat belajar peserta didik kelas III ketika pembelajaran tanpa menggunakan aplikasi belajar Quizizz serta menganalisis dan mendeskripsikan minat belajar peserta didik kelas III ketika pembelajaran menggunakan aplikasi belajar Quizizz.

\section{Metode}

Penelitian ini menggunakan pendekatan mix method (penelitian kombinasi) yang menggabungkan pendekatan kuantitatif dan kualitatif. jenis penelitian menggunakan penelitian deskriptif dan desain metode yang digunakan yaitu desain metode gabungan paralel, dimana data kuantitatif dan data kualitatif diperoleh secara bersamaan dan dianalisis sesuai teknik analisis data yang ada (Sarwono, 2011). Data kuantitatif dalam penelitian ini dipergunakan untuk melihat bagaimana minat belajar peserta didik di kelas III B SDN Bumiayu 
3 Kota Malang yang diperoleh dari hasil kuesioner minat belajar peserta didik. Kuesioner minat belajar peserta didik terdiri dari 20 butir pernyataan positif dan termasuk angket tertutup. Selanjutnya hasil analisis data kualitatif diperoleh dari wawancara dengan guru kelas III B SDN Bumiayu 3 Kota Malang terkait minat belajar peserta didik dalam penggunaan aplikasi belajar Quizizz yang digunakan sebagai pelengkap dan berfungsi untuk memberikan penjelasan nilainilai dari data kuantitatif. Pedoman wawancara terdiri dari 15 butir pertanyaan. Kisi-kisi kuesioner minat belajar peserta didik dan kisi-kisi pedoman wawancara guru dapat dilihat pada Tabel 1 dan Tabel 2. Melalui teknik ini, peneliti dapat menganalisis dan mendeskripsikan tentang minat belajar peserta didik dalam penggunaan aplikasi belajar Quizizz dilihat dari indikator minat belajar perasaan senang, ketertarikan, perhatian, dan keterlibatan. Kategori persentase minat belajar dapat dilihat pada Tabel 3 .

Tabel 1. Kisi-Kisi Kuesioner Minat Belajar Peserta Didik

\begin{tabular}{cllc}
\hline No & Indikator Minat yang Diamati & \multicolumn{1}{c}{ Kriteria Pertanyaan } & Nomor item \\
\hline 1. & Perasaan senang peserta didik & Semangat belajar & 1,4 \\
& & Kesadaran ingin belajar & 2 \\
& & Keseriusan belajar & 5 \\
& & Kemauan belajar & 3 \\
2. & \multirow{2}{*}{ Ketertarikan peserta didik } & Ketertarikan peserta didik pada guru & 8 \\
& & Ketertarikan pada mata pelajaran & 6,7 \\
& & Ketertarikan situasi belajar & 9,10 \\
3. & \multirow{2}{*}{ Perhatian peserta didik } & Konsentrasi belajar & $11,14,13$ \\
& & Kenyamanan belajar & 12,15 \\
4. & \multirow{2}{*}{ Keterlibatan peserta didik } & Frekuensi belajar & 16 \\
& & Pemanfaatan waktu belajar & 17,18 \\
& & Hasrat belajar & 19,20 \\
\hline
\end{tabular}

Sumber: Adaptasi dari Situmorang \& Siahaan (2019)

Tabel 2. Kisi-Kisi Pedoman Wawancara Guru

\begin{tabular}{lllc}
\hline No & Indikator Minat yang Diamati & \multicolumn{1}{c}{ Kriteria Pertanyaan } & Nomor item \\
\hline 1. & Perasaan senang peserta didik & Semangat belajar & 1 \\
& & Kesadaran ingin belajar & 2,3 \\
& & Keseriusan belajar & 4 \\
& & Kemauan belajar & 5 \\
2. & \multirow{2}{*}{ Ketertarikan peserta didik } & Ketertarikan peserta didik pada guru & 6 \\
& & Ketertarikan pada mata pelajaran & 7 \\
& & Ketertarikan situasi belajar & 8,9 \\
3. & \multirow{2}{*}{ Perhatian peserta didik } & Konsentrasi belajar & 10 \\
& & Kenyamanan belajar & 11,12 \\
4. & \multirow{2}{*}{ Keterlibatan peserta didik } & Frekuensi belajar & 13 \\
& & Pemanfaatan waktu belajar & 14 \\
& & Hasrat belajar & 15 \\
\hline
\end{tabular}

Sumber: Adaptasi dari Situmorang \& Siahaan (2019) 
Tabel 3. Kategori Persentase Minat Belajar

\begin{tabular}{ll}
\cline { 2 - 2 } Persentase & Kategori \\
\cline { 2 - 3 } $85 \%<$ skor $\leq 100 \%$ & Sangat Tinggi \\
$70 \%<$ skor $\leq 85 \%$ & Tinggi \\
$55 \%<$ skor $\leq 70 \%$ & Sedang \\
$40 \%<$ skor $\leq 55 \%$ & Rendah \\
$0 \%<$ skor $\leq 40 \%$ & Sangat Rendah \\
\hline Sumber: Adaptasi dari Asria, dkk. $(2021)$ &
\end{tabular}

Data yang dikumpulkan dari penelitian ini yaitu (1) hasil kuesioner minat belajar peserta didik tanpa menggunakan aplikasi belajar Quizizz, (2) hasil kuesioner minat belajar peserta didik dalam penggunaan aplikasi belajar Quizizz, (3) hasil wawancara dengan guru kelas III B mengenai minat belajar peserta didik dalam penggunaan aplikasi belajar Quizizz. Data-data tersebut akan diperkuat dengan dokumentasi.

Subjek selaku sumber data yang terlibat pada penelitian ini yaitu seluruh peserta didik kelas III B SDN Bumiayu 3 Kota Malang yang berjumlah 31 peserta didik dan guru kelas III B SDN Bumiayu 3 Kota Malang. Teknik pengumpulan data pada penelitian ini menggunakan kuesioner atau angket, wawancara, dan dokumentasi. Sedangkan analisis data dimulai dari pengumpulan data, reduksi data, penyajian data, dan penarikan kesimpulan. Keabsahan data dilakukan dengan triangulasi sumber dan metode.

\section{Hasil dan Pembahasan}

\subsection{Minat Belajar Peserta Didik tanpa Menggunakan Aplikasi Belajar Quizizz}

Minat belajar peserta didik tanpa menggunakan aplikasi belajar Quizizz dapat diketahui melalui pengisian kuesioner minat belajar peserta didik tanpa menggunakan aplikasi belajar Quizizz. Media pembelajaran yang digunakan pada kuesioner ini adalah aplikasi WhatsApp, karena aplikasi WhatsApp merupakan media pembelajaran yang biasa digunakan guru dalam pembelajaran di kelas III B SDN Bumiayu 3 Kota Malang. Sejalan dengan itu media pembelajaran merupakan alat bantu untuk menyampaikan sesuatu melalui proses pembelajaran untuk mencapai tujuan tertentu (Centauri, 2019). Pada jenjang sekolah dasar kelas rendah aplikasi yang efektif digunakan dalam proses pembelajaran dalam jaringan yaitu aplikasi WhatsApp Group (Astini, 2020). Hasil rekapitulasi secara umum minat belajar peserta didik tanpa menggunakan aplikasi belajar Quizizz dapat ditunjukkan pada Tabel 4.

Tabel 4. Rekapitulasi Kuesioner Minat Belajar Peserta Didik tanpa Menggunakan Aplikasi Belajar Quizizz

\begin{tabular}{clcccc}
\hline No. & Opsi Jawaban & f & Skor & Total Skor (\%) & Kategori \\
\hline 1. & Sangat Setuju & 19 & 76 & 1568 & Sedang \\
2. & Setuju & 336 & 1008 & $(63 \%)$ & \\
3. & Tidak Setuju & 219 & 438 & & \\
4. & Sangat Tidak Setuju & 46 & 46 & & \\
\hline
\end{tabular}

Berdasarkan Tabel 4 di atas, persentase keseluruhan minat belajar peserta didik kelas III B SDN Bumiayu 3 Kota Malang tanpa menggunakan aplikasi belajar Quizizz yaitu 63\% 
dengan kategori sedang. Dilihat dari hasil persentase secara keseluruhan dengan kategori sedang menandakan kebanyakan peserta didik merasa nyaman apabila pembelajaran tanpa menggunakan aplikasi belajar Quizizz. Hal ini dikarenakan aplikasi yang biasa digunakan selama pembelajaran dalam jaringan berbantuan dengan aplikasi WhatsApp sehingga peserta didik sudah terbiasa dengan pembelajaran dan media yang digunakan. Pada dasarnya minat adalah perhatian yang bersifat khusus. Beberapa faktor yang mempengaruhi minat belajar yaitu (1) motivasi dan cita-cita, (2) keluarga, (3) peranan guru, (4) sarana dan prasarana, (5) teman pergaulan, dan (6) media massa (Simbolon, 2014). Oleh sebab itu, perlu adanya dukungan antara beberapa faktor tersebut agar minat belajar peserta didik dapat meningkat. Selanjutnya hasil minat belajar peserta didik tanpa menggunakan aplikasi belajar Quizizz jika dilihat dari empat indikator minat belajar yaitu (a) perasaan senang, (b) ketertarikan, (c) perhatian, (d) keterlibatan ditunjukkan pada Gambar 1.

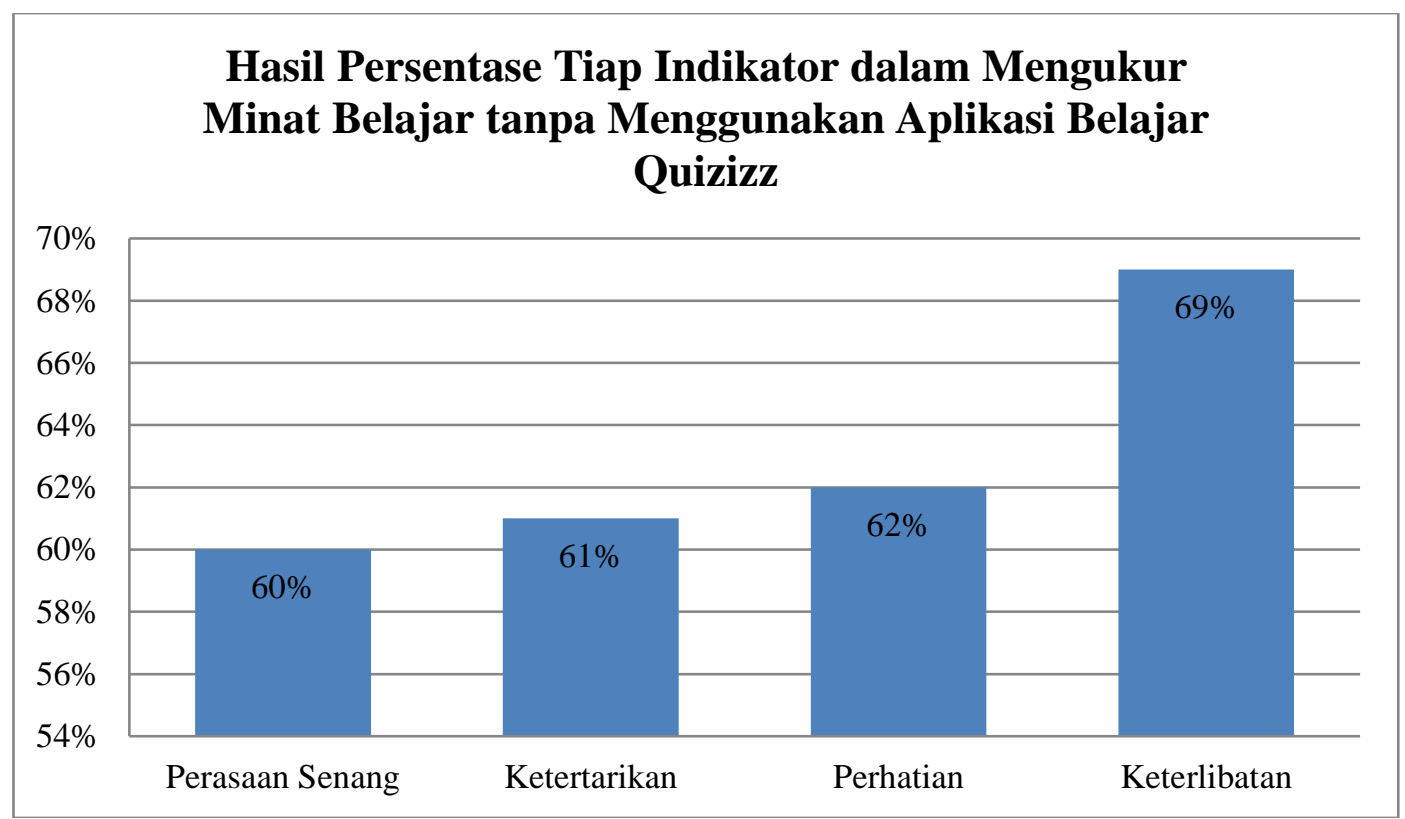

Gambar 1. Hasil Persentase Tiap Indikator Minat Belajar Peserta Didik tanpa Menggunakan Aplikasi Belajar Quizizz

Berdasarkan Gambar 1 di atas, hasil persentase tiap indikator minat belajar peserta didik tanpa menggunakan aplikasi belajar Quizizz diukur menggunakan empat indikator minat belajar. Pada indikator yang pertama yaitu perasaan senang, hasil persentase memperoleh $60 \%$ dengan total skor 372 yang dikategorikan sedang. Indikator yang kedua yaitu ketertarikan, hasil persentase memperoleh $61 \%$ dengan total skor 380 yang dikategorikan sedang. Indikator yang ketiga yaitu perhatian, hasil persentase memperoleh $62 \%$ dengan total skor 386 yang dikategorikan sedang. Indikator yang keempat yaitu keterlibatan, hasil persentase $69 \%$ dengan total skor 430 yang dikategorikan sedang. Indikator minat belajar yang memperoleh hasil persentase tertinggi yaitu indikator keterlibatan. Sejalan dengan itu salah satu ciri peserta didik yang berminat belajar yaitu menuangkan melalui partisipasi atau terlibat secara langsung dalam kegiatan (Slameto, 2003). Minat belajar peserta didik dapat dilihat dari kesukaan, perhatian peserta didik, ketertarikan, dan keterlibatan peserta didik dalam kegiatan belajar (Sudaryono, 2012). Semakin peserta didik berminat belajar maka tidak menutup kemungkinan bahwa proses belajar akan berjalan dengan baik serta hasil belajar yang diperoleh pun juga baik. 


\subsection{Minat Belajar Peserta Didik dalam Penggunaan Aplikasi Belajar Quizizz}

Minat belajar peserta didik dalam penggunaan aplikasi belajar Quizizz dapat diketahui melalui pengisian kuesioner minat belajar peserta didik menggunakan aplikasi belajar Quizizz. Media pembelajaran yang digunakan pada kuesioner ini adalah aplikasi Quizizz, karena aplikasi belajar Quizizz merupakan media pembelajaran berbasis permainan yang sangat menarik bagi peserta didik di jenjang sekolah dasar. Utamanya pada kelas III yang memiliki karakteristik menyukai kegiatan pembelajaran yang dikaitkan dengan permainan. Aplikasi belajar Quizizz dapat membantu guru untuk mengetahui tingkat pemahaman peserta didik secara cepat dan akurat serta memberikan semangat dan pengalaman baru dalam kegiatan pembelajaran (Adianto, 2020). Pembelajaran yang berbantuan dengan aplikasi belajar Quizizz dapat membantu guru untuk mengetahui sejauh mana kemampuan dan pengetahuan peserta didiknya pada setiap soal kuis yang diberikan (Kinanti \& Subagio, 2020). Hasil rekapitulasi secara umum minat belajar peserta didik dalam penggunaan aplikasi belajar Quizizz dapat ditunjukkan pada Tabel 5.

Tabel 5. Rekapitulasi Kuesioner Minat Belajar Peserta Didik dalam Penggunaan Aplikasi Belajar Quizizz

\begin{tabular}{clcccc}
\hline No. & Opsi Jawaban & f & Skor & Total Skor (\%) & Kategori \\
\hline 1. & Sangat Setuju & 225 & 900 & 2053 & Sedang \\
2. & Setuju & 363 & 1089 & $(83 \%)$ & \\
3. & Tidak Setuju & 32 & 64 & & \\
4. & Sangat Tidak Setuju & 0 & 0 & & \\
\hline
\end{tabular}

Berdasarkan Tabel 5 di atas, persentase keseluruhan minat belajar peserta didik kelas III B SDN Bumiayu 3 Kota Malang menggunakan aplikasi belajar Quizizz yaitu 83\% dengan kategori tinggi. Hasil persentase minat belajar secara keseluruhan dengan kategori tinggi menandakan kebanyakan peserta didik merasa lebih berminat belajar apabila pembelajaran menggunakan aplikasi belajar Quizizz. Peserta didik sangat tertarik dan lebih antusias apabila pembelajaran atau tugas diberikan melalui aplikasi belajar Quizizz. Dilihat dari proses pengumpulan tugas yang lebih cepat dan disiplin serta hasil yang diperoleh, peserta didik lebih menyukai aplikasi belajar Quizizz. Peserta didik sangat menyukai cara guru dalam memberikan pembelajaran tematik jika menggunakan aplikasi belajar Quizizz. Peserta didik yang memiliki minat belajar tinggi cenderung tekun, ulet, semangat dalam belajar, pantang menyerah dan senang menghadapi tantangan (Lestari, 2015). Pembelajaran tematik terasa lebih menyenangkan apabila menggunakan aplikasi belajar Quizizz karena aplikasi belajar Quizizz menyediakan fitur-fitur yang menarik dan membuat peserta didik bersemangat untuk belajar. Selanjutnya hasil minat belajar peserta didik dalam penggunaan aplikasi belajar Quizizz jika dilihat dari empat indikator minat belajar yaitu (a) perasaan senang, (b) ketertarikan, (c) perhatian, (d) keterlibatan ditunjukkan pada Gambar 2. 


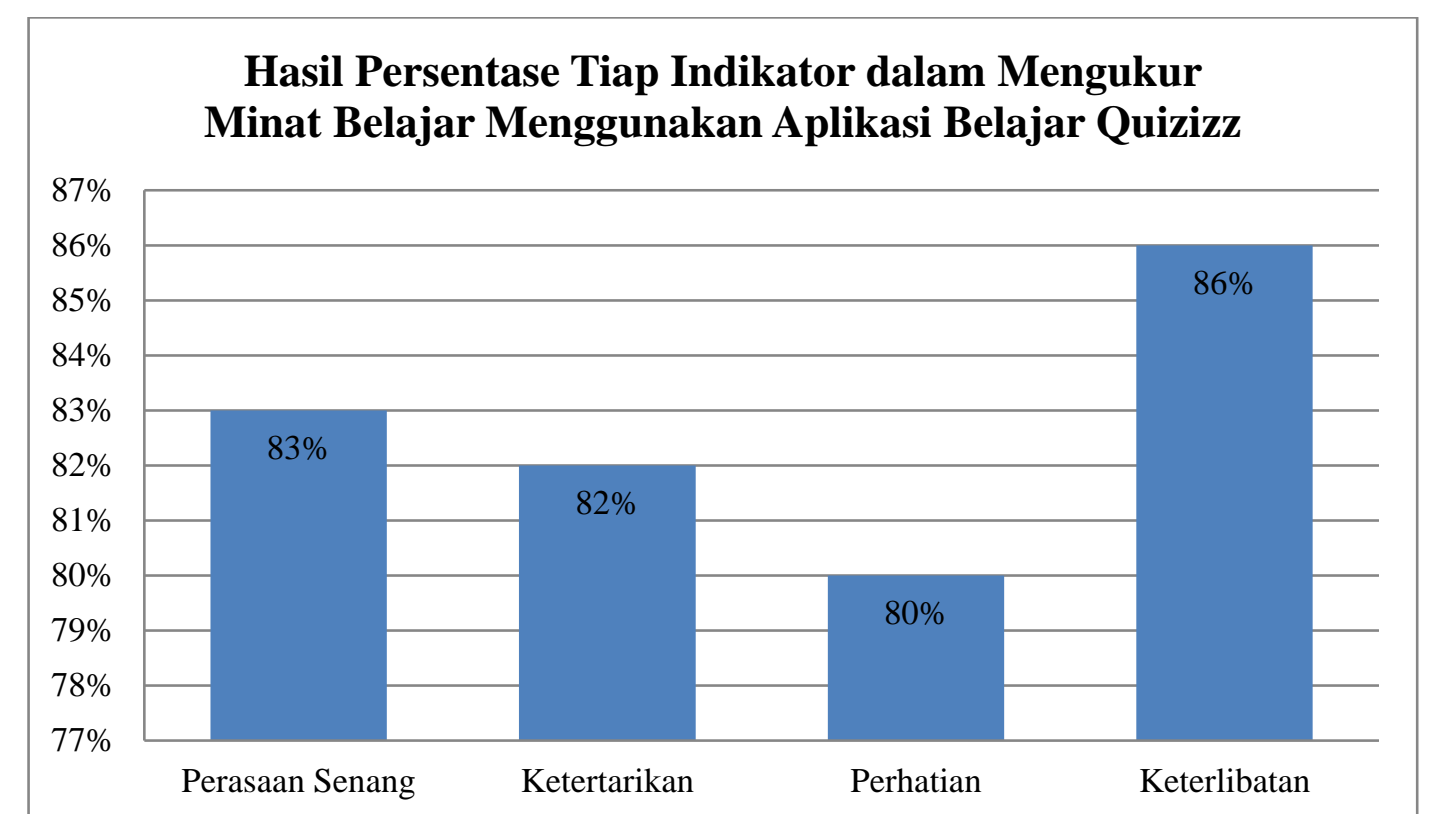

\section{Gambar 2. Hasil Persentase Tiap Indikator Minat Belajar Peserta Didik dalam Penggunaan Aplikasi Belajar Quizizz}

Berdasarkan Gambar 2 di atas, hasil persentase tiap indikator minat belajar peserta didik dalam penggunaan aplikasi belajar Quizizz diukur menggunakan empat indikator minat belajar. Pada indikator yang pertama yaitu perasaan senang, hasil persentase memperoleh 83\% dengan total skor 516 yang dikategorikan tinggi. Berdasarkan hasil kuesioner minat belajar peserta didik dalam penggunaan aplikasi belajar Quizizz pada indikator perasaan senang yang termasuk kategori tinggi dapat diartikan bahwa penggunaan aplikasi belajar Quizizz akan membuat peserta didik senang dalam mengerjakan tugas tematik tanpa merasa bosan dan tertekan dalam pengerjaannya. Seorang peserta didik yang memiliki perasaan senang atau suka terhadap sesuatu pembelajaran maka ia akan terus belajar tanpa ada perasaan terpaksa untuk mempelajarinya (Situmorang \& Siahaan, 2019). Peserta didik merasa senang apabila belajar dengan aplikasi belajar Quizizz dikarenakan aplikasi belajar Quizizz merupakan aplikasi belajar berbasis permainan berkarakter menarik seperti avatar, tema, meme, dan musik yang dapat menghibur peserta didik dalam proses pengerjaan soal.

Berdasarkan hasil persentase indikator yang kedua yaitu ketertarikan memperoleh 82\% dengan total skor 507 yang dikategorikan tinggi dapat diartikan bahwa peserta didik merasa tertarik belajar menggunakan aplikasi belajar Quizizz. Hal ini dikarenakan adanya papan peringkat (leaderboard) yang ditampilkan, sehingga memotivasi peserta didik untuk bersaing dengan teman lainnya dan segera mengerjakan dengan cepat dan tepat setiap kali selesai mengerjakan satu soal. Aplikasi belajar Quizizz memungkinkan peserta didik untuk saling bersaing dan memotivasi belajar peserta didik sehingga hasil belajar bisa meningkat (Mulyati \& Evendi, 2020).

Indikator yang ketiga yaitu perhatian, hasil persentase memperoleh $80 \%$ dengan total skor 495 yang dikategorikan tinggi. Perhatian peserta didik dapat dikategorikan tinggi karena Adanya papan peringkat (leaderboard) sehingga peserta didik mengerjakan tugas tematik dengan penuh konsentrasi dan bersungguh-sungguh untuk memperoleh hasil belajar yang baik. Hasil persentase pada indikator perhatian ini merupakan perolehan paling rendah daripada hasil persentase pada indikator minat belajar menggunakan aplikasi belajar Quizizz 
yang lainnya. Hal ini dikarenakan kenyamanan belajar peserta didik yang masih kurang. Peserta didik belum terbiasa menggunakan aplikasi belajar Quizizz ketika pembelajaran dalam jaringan. Memperhatikan merupakan suatu yang mudah dilakukan oleh peserta didik apabila dalam diri peserta didik terdapat motivasi atau dorongan untuk memperhatikan sesuatu (Asria, dkk., 2021). Maka seorang guru harus mampu membangkitkan minat peserta didik terutama ketika kegiatan pembelajaran atau pada saat evaluasi pembelajaran.

Selanjutnya indikator yang keempat yaitu keterlibatan, hasil persentase 86\% dengan total skor 535 yang dikategorikan sangat tinggi. Keterlibatan peserta didik disebabkan oleh rasa tertarik sehingga mengakibatkan peserta didik untuk terlibat atau berpartisipasi dalam kegiatan pembelajaran. Hasil persentase pada indikator keterlibatan ini merupakan perolehan tertinggi daripada hasil persentase pada indikator minat belajar menggunakan aplikasi belajar Quizizz yang lainnya. Hal ini dikarenakan peserta didik langsung mengerjakan tugas tematik yang diberikan melalui aplikasi belajar Quizizz dan mengumpulkannya secara tepat waktu. Peserta didik mengerjakan tugas tematik yang diberikan melalui aplikasi belajar Quizizz secara sungguh-sungguh. Terdapat fitur aplikasi belajar Quizizz yang menarik seperti avatar, tema, meme, power-ups, musik dan papan peringkat (leaderboard) yang dapat menghibur serta membantu meningkatkan minat belajar serta semangat peserta didik dalam proses pengerjaan soal. Aplikasi belajar Quizizz dibuat sedemikian rupa supaya efektif, efisien dan meningkatkan daya eksplorasi peserta didik, serta keaktifan dan partisipasi peserta didik secara kompetitif dalam kegiatan pembelajaran sesama temannya (Purba, 2019).

\subsection{Perbandingan Minat Belajar Peserta Didik tanpa Menggunakan dan Menggunakan Aplikasi Belajar Quizizz}

Minat belajar peserta didik kelas III B SDN Bumiayu 3 Kota Malang pada penelitian ini diketahui menggunakan kuesioner minat belajar peserta didik. Kuesioner minat belajar peserta didik yang digunakan yaitu kuesioner minat belajar peserta didik tanpa menggunakan aplikasi belajar Quizizz dan kuesioner minat belajar peserta didik menggunakan aplikasi belajar Quizizz. Minat belajar peserta didik dilihat dari empat indikator minat belajar yaitu (a) perasaan senang, (b) ketertarikan, (c) perhatian, (d) keterlibatan. Perbandingan hasil minat belajar peserta didik yang diperoleh melalui kuesioner minat belajar peserta didik dapat dilihat pada Tabel 6 .

Tabel 6. Perbandingan Hasil Minat Belajar Peserta Didik tanpa Menggunakan dan Menggunakan Aplikasi Belajar Quizizz

\begin{tabular}{lccc}
\hline $\begin{array}{c}\text { Indikator Minat } \\
\text { Belajar }\end{array}$ & $\begin{array}{c}\text { Hasil Skor Kuesioner Minat } \\
\text { Belajar tanpa Menggunakan } \\
\text { Aplikasi Belajar Quizizz (\%) }\end{array}$ & $\begin{array}{c}\text { Hasil Skor Kuesioner Minat } \\
\text { Belajar Menggunakan } \\
\text { Aplikasi Belajar Quizizz (\%) }\end{array}$ & Selisih (\%) \\
\hline Perasaan Senang & 372 & 516 & 144 \\
Ketertarikan & $(60.00 \%)$ & $(83.22 \%)$ & $(23.22 \%)$ \\
& 380 & 507 & 127 \\
Perhatian & $(61.29 \%)$ & $(81.77 \%)$ & $(20.48 \%)$ \\
& 386 & 495 & 109 \\
Keterlibatan & $(62.25 \%)$ & $(79.83 \%)$ & $(17.58 \%)$ \\
& 430 & 535 & 105 \\
Total Hasil & $(69.35 \%)$ & $(86.29 \%)$ & $(16.94 \%)$ \\
Kuesioner & $\mathbf{1 5 6 8}$ & $\mathbf{2 0 5 3}$ & $\mathbf{4 8 5}$ \\
& $\mathbf{( 6 3 . 2 2 \% )}$ & $\mathbf{( 8 2 . 7 3 \% )}$ & $\mathbf{( 1 9 . 5 1 \% )}$ \\
\hline
\end{tabular}


Berdasarkan tabel 6 perbandingan hasil minat belajar peserta didik di kelas III B SDN Bumiayu 3 Kota Malang tanpa menggunakan aplikasi belajar Quizizz dan menggunakan aplikasi belajar Quizizz dapat diketahui hasil minat belajar tanpa menggunakan aplikasi belajar Quizizz yaitu 63.22\% dan hasil minat belajar menggunakan aplikasi belajar Quizizz yaitu 82.73\%. Terdapat selisih peningkatan $19.51 \%$ atau apabila dibulatkan menjadi $20 \%$. Selisih peningkatan yang hanya terhitung $20 \%$ ini disebabkan peserta didik masih terbiasa dengan cara guru ketika memberikan pembelajaran tematik tanpa menggunakan aplikasi belajar Quizizz sehingga di awal pengerjaan, peserta didik mengalami kesulitan dalam mengoperasikan aplikasi belajar Quizizz ketika pembelajaran dalam jaringan dikarenakan belum terbiasa. Akan tetapi, peserta didik sangat menyukai cara guru dalam memberikan pembelajaran tematik menggunakan aplikasi belajar Quizizz. Aplikasi belajar Quizizz membantu kegiatan belajar dan mengajar menjadi lebih menarik minat dan motivasi peserta didik untuk terus belajar dengan materi-materi yang telah dipelajari menjadi sebuah kuis yang membuat daya saing peserta didik satu dengan yang lain terpacu yang lainnya (Adianto, 2020). Terdapat peningkatan ketertarikan peserta didik ketika pembelajaran tematik menggunakan aplikasi belajar Quizizz meskipun peningkatannya hanya terhitung 20\%. Adanya peningkatan minat belajar peserta didik menunjukkan aplikasi belajar Quizizz dapat digunakan sebagai media pembelajaran yang menarik dan dapat membantu guru untuk meningkatkan minat belajar peserta didik di jenjang sekolah dasar.

Berdasarkan paparan di atas, dapat dikemukakan implikasi secara teoritis yaitu pemilihan media evaluasi pembelajaran memiliki pengaruh terhadap minat belajar peserta didik dalam mengerjakan tugas yang nantinya akan memiliki pengaruh juga pada hasil belajar peserta didik yang diperoleh. Aplikasi belajar Quizizz merupakan aplikasi berbasis permainan yang dapat digunakan sebagai media evaluasi pembelajaran (Citra \& Rosy, 2020). Aplikasi belajar Quizizz membantu guru dalam kegiatan evaluasi pembelajaran untuk mengetahui tingkat pemahaman peserta didik secara cepat dan akurat serta memberikan semangat dan pengalaman baru dalam kegiatan pembelajaran (Adianto, 2020). Hasil penelitian ini berimplikasi bahwa guru perlu melakukan variasi dalam kegiatan belajar mengajar utamanya dalam evaluasi pembelajaran agar tercipta suasana belajar yang menyenangkan, tidak monoton serta memanfaatkan teknologi. Jadi, berdasarkan hasil analisis data yang sudah dilakukan dan merujuk teori serta penelitian sebelumnya dapat disimpulkan bahwa penggunaan aplikasi belajar Quizizz sebagai media pembelajaran dapat menjadi alternatif guru dalam meningkatkan minat belajar peserta didik pada kegiatan pembelajaran dan evaluasi pembelajaran.

\section{Simpulan}

Berdasarkan hasil penelitian, minat belajar peserta didik kelas III B SDN Bumiayu 3 Kota Malang tanpa menggunakan aplikasi belajar Quizizz secara keseluruhan tergolong sedang dengan persentase $63 \%$. Hasil persentase tiap indikator pada kuesioner minat belajar peserta didik tanpa menggunakan aplikasi belajar Quizizz pada indikator perasaan senang memperoleh $60 \%$ dengan kategori sedang, indikator ketertarikan memperoleh $61 \%$ yang dikategorikan sedang, indikator perhatian hasil persentase memperoleh $62 \%$ yang termasuk kategori sedang dan indikator yang keempat yaitu keterlibatan memperoleh $69 \%$ yang termasuk kategori sedang. Selanjutnya dapat disimpulkan bahwa minat belajar peserta didik tanpa menggunakan aplikasi belajar Quizizz tergolong sedang dikarenakan peserta didik sudah merasa nyaman dan terbiasa apabila pembelajaran tanpa menggunakan aplikasi belajar 
Quizizz. Peserta didik sudah terbiasa dengan pembelajaran dan media yang digunakan guru selama pembelajaran dalam jaringan.

Berdasarkan hasil penelitian, minat belajar peserta didik dalam penggunaan aplikasi belajar Quizizz mengalami peningkatan. Hasil persentase keseluruhan minat belajar peserta didik kelas III B SDN Bumiayu 3 Kota Malang menggunakan aplikasi belajar Quizizz yaitu 83\% yang termasuk kategori tinggi. Hasil persentase tiap indikator pada kuesioner minat belajar peserta didik menggunakan aplikasi belajar Quizizz pada indikator perasaan senang memperoleh 83\% dengan kategori tinggi, indikator ketertarikan memperoleh $82 \%$ yang dikategorikan tinggi, indikator perhatian hasil persentase memperoleh $80 \%$ yang termasuk kategori tinggi dan indikator yang keempat yaitu keterlibatan memperoleh 86\% yang termasuk kategori sangat tinggi. Selanjutnya dapat disimpulkan bahwa aplikasi belajar Quizizz dapat menjadi alternatif guru dalam menggunakan media pembelajaran selama pembelajaran dalam jaringan di masa pandemi guna meningkatkan minat belajar peserta didik, serta menciptakan suasana pembelajaran yang lebih menarik, menyenangkan, tidak monoton untuk diikuti peserta didik, dan memanfaatkan teknologi.

Peningkatan minat belajar peserta didik yang terhitung 20\% ini dikarenakan peserta didik sangat menyukai cara guru dalam memberikan pembelajaran tematik menggunakan aplikasi belajar Quizizz. Terdapat peningkatan ketertarikan peserta didik ketika pembelajaran tematik menggunakan aplikasi belajar Quizizz meskipun peningkatannya hanya terhitung $20 \%$. Selisih peningkatan yang hanya terhitung $20 \%$ ini disebabkan peserta didik masih terbiasa dengan cara guru ketika memberikan pembelajaran tematik tanpa menggunakan aplikasi belajar Quizizz sehingga di awal pengerjaan, peserta didik mengalami kesulitan dalam mengoperasikan aplikasi belajar Quizizz ketika pembelajaran dalam jaringan dikarenakan belum terbiasa.

\section{Daftar Rujukan}

Adianto, S. (2020). Penerapan Scientific dan Cooperative Learning dengan Quis Online untuk Meningkatkan Hasil Belajar Siswa Sekolah Dasar. JINOTEP (Jurnal Inovasi dan Teknologi Pembelajaran): Kajian dan Riset dalam Teknologi Pembelajaran, 7(1), 57-65.

Aini, Y. I. (2019). Pemanfaatan Media Pembelajaran Quizizz untuk Pembelajaran Jenjang Pendidikan Dasar dan Menengah di Bengkulu. Kependidikan, 2(25).

Amri, M., \& Shobri, Y. A. (2020). Persepsi Mahasiswa terhadap Penggunaan Quizizz dalam Pembelajaran Akuntansi Konsolidasi Bank Syariah di IAIN Ponorogo.Jurnal Teknologi Informasi dan Pendidikan, 13(1), 128-136.

Asria, L., Sari, D. R., Ngaini, S. A., Muyasaroh, U., \& Rahmawati, F. (2021). Analisis Antusiasme Siswa dalam Evaluasi Belajar Menggunakan Platform Quizizz. Alifmatika: Jurnal Pendidikan Dan Pembelajaran Matematika, 3(1), 1-17.

Astini, N. K. S. (2020). Pemanfaatan Teknologi Informasi dalam Pembelajaran Tingkat Sekolah Dasar pada Masa Pandemi Covid-19. Lampuhyang, 11(2), 13-25.

Centauri, B. (2019). Efektivitas Kahoot! Sebagai Media Pembelajaran Kuis Interaktif di SDN-7 Bukit Tunggal. In Prosiding Seminar Nasional Pendidikan MIPA dan Teknologi II (Vol. 1, No. 1, pp. 124-133).

Citra, C. A., \& Rosy, B. (2020). Keefektifan Penggunaan Media Pembelajaran Berbasis Game Edukasi Quizizz terhadap Hasil Belajar Teknologi Perkantoran Siswa Kelas X SMK Ketintang Surabaya.Jurnal Pendidikan Administrasi Perkantoran (JPAP), 8(2), 261-272.

Dayanti, R. N., Herlambang, A. D., \& Wijoyo, S. H. (2020). Pengaruh Kualitas Implementasi Metode Pembelajaran Ceramah Berbantuan Powerpoint dan Quizizz terhadap Hasil Belajar Kognitif dan Psikomotorik Mata Pelajaran Desain Grafis Percetakan di SMK Negeri 12 Malang. Jurnal Pengembangan Teknologi Informasi dan Ilmu Komputer. 
Djamarah, B. S. (2011). Psikologi Belajar. Jakarta: Rineka Cipta.

Gusty, S., Nurmiati, N., Muliana, M., Sulaiman, O. K., Ginantra, N. L. W. S. R., Manuhutu, M. A., ... \& Hastuti, P. (2020). Belajar Mandiri: Pembelajaran Daring di Tengah Pandemi Covid-19. Medan: Yayasan Kita Menulis.

Kartini, T. (2007). Penggunaan Metode Role Playing untuk Meningkatkan Minat Siswa dalam Pembelajaran Pengetahuan Sosial di Kelas V SDN Cileunyi I Kecamatan Cileunyi Kabupaten Bandung. Jurnal Pendidikan Dasar, 8(1), 16-17.

Lestari, I. (2015). Pengaruh Waktu Belajar dan Minat Belajar terhadap Hasil Belajar Matematika. Formatif: Jurnal Ilmiah Pendidikan MIPA, 3(2).

Muis, A. (2019). Konsep dan Strategi Pembelajaran di Era Revolusi Industri 4.0. Yogyakarta: Laksana.

Mulyati, S., \& Evendi, H. (2020). Pembelajaran Matematika Melalui Media Game Quizizz untuk Meningkatkan Hasil Belajar Matematika SMP 2 Bojonegara. GAUSS: Jurnal Pendidikan Matematika, 3(1), 64-73.

Nissa, S. F., \& Haryanto, A. (2020). Implementasi Pembelajaran Tatap Muka di Masa Pandemi Covid-19. Jurnal IKA PGSD (Ikatan Alumni PGSD) UNARS, 8(2), 402-409.

Praherdhiono, H., Adi, E. P., Prihatmoko, Y., Nindigraha, N., Soepriyanto, Y., Indreswari, H., \& Oktaviani, H. I. (2020). Implementasi Pembelajaran di Era dan Pasca Pandemi Covid-19. Malang: CV Seribu Bintang.

Pujiasih, E. (2020). Membangun Generasi Emas dengan Variasi Pembelajaran Online di Masa Pandemi Covid19. Ideguru: Jurnal Karya Ilmiah Guru, 5(1), 42-48.

Purba, L. S. L. (2019). Peningkatan Konsentrasi Belajar Mahasiswa Melalui Pemanfaatan Evaluasi Pembelajaran Quizizz pada Mata Kuliah Kimia Fisika I. Jurnal Dinamika Pendidikan, 12(1), 29.

Quizizz. (2020). How to use Lessons Before, After, and During Class, (Online), (https://blog.Quizizz.com/howto-use-lessons-before-after-and-during-class-5993f6720475), diakses 17 Maret 2021.

Sarwono, J. (2011). Mixed Methods: Cara Menggabung Riset Kuantitatif dan Riset Kualitatif Secara Benar. Jakarta: PT Elex Media Komputindo.

Simbolon, N. (2014). Faktor-Faktor yang Mempengaruhi Minat Belajar Peserta Didik. Elementary School Journal Pgsd Fip Unimed, 1(2).

Situmorang, A. S., \& Siahaan, F. B. (2019). Desain Model Pencapaian Konsep terhadap Minat Belajar Mahasiswa FKIP UHN. Jurnal Penelitian Bidang Pendidikan, 25(1), 55-61.

Slameto. (2003). Belajar dan Faktor-faktor yang Mempengaruhinya. Jakarta: Rineka Cipta.

Slameto. (2010). Belajar dan Faktor-faktor yang Mempengaruhinya. Jakarta: Rineka Cipta.

Sudaryono. (2012). Dasar-Dasar Evaluasi Pembelajaran. Yogyakarta: Graha Ilmu. 